\title{
High Dosage Metolazone in Chronic Renal Failure
}

\author{
H. J. DARGIE, MARJORIE E. M. ALLISON, A. C. KENNEDY, MARY J. B. GRAY
}

diuretic and natriuretic substance (Materson and Barkin, 1970;

\section{Summary}

Metolazone is a modified quinazolinesulphonamide and in a dose of between 4 and $7.5 \mathrm{mg}$ is an effective diuretic in man with normal renal function. Fourteen patients with non-oedematous stable chronic renal failure (creatinine clearance ranging from 1.2 to $12 \mathrm{ml} / \mathrm{min}$ ) were given metolazone in doses ranging from $20-150 \mathrm{mg}$. A noticeable increase in urine flow and sodium excretion occurred, free water clearance increased, and there was a small but significant increase in potassium excretion. No side efiects were noted.

\section{Introduction}

Frusemide in high dosage can be an effective diuretic in patients with severe renal impairment (Dettli and Spring, 1966; Laragh et al., 1966; McKenzie et al., 1966; Muth, 1966, 1968; Silverberg and Kjellstrand, 1968; Allison and Kennedy, 1971) and ethacrynic acid can also be of value in this situation (Maher and Schreiner, 1965). High dosage diuretic therapy may now be regarded as a significant advance in the management of patients with chronic renal failure (Lancet, 1971) since other commonly-used diuretics such as the thiazides are ineffective at glomerular filtration rates of less than $15-20 \mathrm{ml} / \mathrm{min}$ (Reubi and Cottier, 1961).

We report on the acute effect of a new preparation, metolazone, in patients with grossly impaired renal function. Metolazone has the formula 2 methyl-3-(o-tolyl)-6-sulphamyl-7-chloro1,2,3,4-tetrahydro-4-quinazolionone and is structurally related to the sulphonamides and benzothiadiazine diuretics. It is similar to quinethazone but differs from that compound by the replacement of the ethyl group in position 2 with a methyl group, and by the introduction of the o-tolyl group in position 3 . Studies in normal man have shown metolazone to be a potent

\footnotetext{
University Department of Medicine and Renal Unit, Royal Infirmary, Glasgow

H. J. DARGIE, M.B., M.R.C.P., Registrar in Medicine

MARJORIE E. M. ALLISON, M.B., M.R.C.P., Lecturer in Medicine

A. C. KENNEDY, M.D., F.R.C.P., Professor of Medicine

MARY J. B. GRAY, B.SC., Biochemist
}

Steinmuller and Puschett, 1971, 1972).

\section{Patients and Methods}

Sixteen acute studies were performed on 14 patients with their agreement. Each patient had relatively stable, non-oedematous chronic renal failure due to glomerulonephritis (8), pyelonephritis (4), and polycystic kidneys (2) (Table I). One patient (Study No. 14, 15, and 16) was studied three times with increasing doses (Table II). There were seven men and seven women ranging in age from 18 to 72 years.

The creatinine clearance values ranged from $1.2-12 \mathrm{ml} / \mathrm{min}$ with a mean of $4 \cdot 2$. No patient had received a diuretic in the previous two weeks, and tea, coffee, and smoking were not allowed on the day of the study, during which there was no restriction of normal activities. Previous dietary regimens were maintained in the individual patients without specific monitoring of sodium and potassium intake.

To study the effect of the drug on free water clearance each patient was water loaded. One litre of water was given at 8 a.m. followed by further amounts every two hours equal to the volume of urine passed. Urine samples were collected at two-hourly intervals from 8 a.m. to 10 p.m., and plasma samples at similar intervals from 9 a.m. to 11 p.m. A further 10-hour sample of urine was collected from 10 p.m. to 8 a.m. to assess any late effect of the drug. Twenty-four-hour urine samples were collected on

TABLB I-Clinical Data on the 14 Patients in the Study

\begin{tabular}{|c|c|c|c|}
\hline $\begin{array}{l}\text { Study } \\
\text { No. }\end{array}$ & $\begin{array}{l}\text { Age and } \\
\text { Sex }\end{array}$ & Diagnosis & $\begin{array}{l}\text { Creatinine } \\
\text { Clearance } \\
\text { (ml/min) }\end{array}$ \\
\hline $\begin{array}{r}1 \\
2 \\
3 \\
4 \\
5 \\
6 \\
7 \\
7 \\
8 \\
9 \\
10 \\
11 \\
12 \\
13 \\
14 \\
15 \\
16\end{array}$ & $\begin{array}{l}40 \mathrm{M} . \\
53 \mathrm{M} . \\
27 \mathrm{M} . \\
28 \mathrm{~F} . \\
72 \mathrm{~F} . \\
32 \mathrm{~F} . \\
64 \mathrm{~F} . \\
40 \mathrm{M} . \\
20 \mathrm{~F} . \\
18 \mathrm{~F} . \\
39 \mathrm{M} . \\
19 \mathrm{M} . \\
22 \mathrm{~F} . \\
37 \mathrm{M} . \\
37 \mathrm{M} . \\
37 \mathrm{M} .\end{array}$ & $\begin{array}{l}\text { Glomerulonephritis } \\
\text { Glomerulonephritis } \\
\text { Glomerulonephritis } \\
\text { Glomerulonephritis } \\
\text { Polycystic kidney } \\
\text { Pyelonephritis } \\
\text { Pyelonephritis } \\
\text { Glomerulonephritis } \\
\text { Glomerulonephris } \\
\text { Pyelonephritis } \\
\text { Polycystic kidney } \\
\text { Glomerulonephritis } \\
\text { Pyemonephritis } \\
\text { Glomerulonephritis } \\
\text { Glomerulonephritis } \\
\text { Glomerulonephritis }\end{array}$ & $\begin{array}{l}6.4 \\
4.7 \\
5.3 \\
6.0 \\
6.8 \\
3.2 \\
2.2 \\
3.5 \\
1.2 \\
5.5 \\
1.8 \\
2.6 \\
12 \\
2.2 \\
2.2 \\
2.2\end{array}$ \\
\hline
\end{tabular}

TABLE II-Results Before and After Administration of Metolazone

\begin{tabular}{|c|c|c|c|c|c|c|c|c|c|c|c|c|c|c|c|c|c|c|c|c|c|}
\hline \multirow{2}{*}{$\begin{array}{l}\text { Study } \\
\text { No. }\end{array}$} & \multirow{2}{*}{$\mid \begin{array}{c}\text { Metolazone } \\
\text { Dose (mg) }\end{array}$} & \multicolumn{3}{|c|}{$\begin{array}{c}\text { Urine Flow } \\
(\mathrm{ml} / \mathrm{min})\end{array}$} & \multicolumn{3}{|c|}{$\underset{(\mu \mathrm{Eq} / \mathrm{min})}{\mathrm{Na}+\text { Excretion }}$} & \multicolumn{3}{|c|}{ 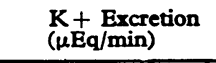 } & \multicolumn{3}{|c|}{$\begin{array}{c}\text { Maximum \% Filtered } \\
\text { Load Na + Excreted }\end{array}$} & \multicolumn{3}{|c|}{$\begin{array}{l}\text { Solute Excretion } \\
\text { ( } \mu \text { Osm/min) }\end{array}$} & \multicolumn{3}{|c|}{$\mathrm{C}_{\mathrm{H}_{3} \mathrm{O}}(\mathrm{ml} / \mathrm{min})$} & \multicolumn{2}{|c|}{$\begin{array}{l}\text { Hours to Mari- } \\
\text { mum Effect on: }\end{array}$} \\
\hline & & B. & A. & Diff. & B. & A. & iff. & B. & A. & iff. & B. & A. & Diff. & B. & A. & Diff. & B. & & Diff. & & $\begin{array}{c}\mathrm{Na}+ \\
\text { Excretion }\end{array}$ \\
\hline $\begin{array}{r}1 \\
2 \\
3 \\
4 \\
5 \\
6 \\
7 \\
8 \\
9 \\
10 \\
11 \\
12 \\
13 \\
14 \\
15\end{array}$ & $\begin{array}{r}20.0 \\
20.0 \\
40.0 \\
40.0 \\
50.0 \\
50.0 \\
100.0 \\
100.0 \\
100.0 \\
150.0 \\
100.0 \\
150.0 \\
50.0 \\
20.0 \\
40.0 \\
60.0\end{array}$ & $\begin{array}{l}1.28 \\
1.17 \\
1.92 \\
0.82 \\
1.04 \\
1.31 \\
2.27 \\
2.14 \\
1.36 \\
1.1 \\
1.67 \\
1.76\end{array}$ & $\begin{array}{l}3.88 \\
2.89 \\
2.42 \\
1.3 \\
1.35 \\
1.35 \\
2.0 \\
3.1 \\
3.42 \\
1.75 \\
1.35 \\
2.50 \\
3.16 \\
3.3\end{array}$ & $\begin{array}{l}0.94 \\
0.9 \\
1.61 \\
1.26 \\
-0.62 \\
0.53 \\
0.31 \\
0.69 \\
0.83 \\
1.28 \\
0.39 \\
0.25 \\
0.83 \\
1.4 \\
1.16\end{array}$ & $\begin{array}{r}48 \\
102 \\
37 \\
44 \\
91 \\
31 \\
38 \\
85 \\
54 \\
32 \\
68 \\
62 \\
45 \\
70 \\
102 \\
74\end{array}$ & $\begin{array}{r}162 \\
172 \\
156 \\
87 \\
86 \\
70 \\
153 \\
158 \\
161 \\
124 \\
100 \\
84 \\
133 \\
107\end{array}$ & $\begin{array}{r}135 \\
112 \\
-4 \\
55 \\
32 \\
68 \\
104 \\
129 \\
56 \\
38 \\
39 \\
63\end{array}$ & $\begin{array}{l}20 \\
32 \\
25 \\
28 \\
14 \\
14 \\
23 \\
26 \\
17 \\
13 \\
26 \\
16 \\
20\end{array}$ & $\begin{array}{l}61 \\
57 \\
16 \\
18 \\
26 \\
26 \\
22 \\
12 \\
39 \\
18 \\
27\end{array}$ & $\begin{array}{r}10 \\
-1 \\
36 \\
29 \\
2 \\
4 \\
3 \\
0 \\
5 \\
-1 \\
13 \\
2 \\
7 \\
7 \\
72 \\
22\end{array}$ & $\begin{array}{r}6.6 \\
17.6 \\
6.6 \\
6.6 \\
10.6 \\
7.7 \\
13.2 \\
19.8 \\
3.3 \\
5.5 \\
288 \\
18.7 \\
2.8 \\
28.6 \\
32 \\
38.5\end{array}$ & $\begin{array}{l}16 \cdot 5 \\
28.6 \\
32.6 \\
24 \cdot 2 \\
10.1 \\
20.9 \\
25 \cdot 9 \\
33 \\
24 \cdot 2 \\
52 \cdot 6 \\
29.7 \\
55.19 \\
47.3 \\
40.7\end{array}$ & $\begin{array}{r}9.9 \\
11 \\
25.5 \\
17.6 \\
-0 \\
13.2 \\
12.1 \\
13 \cdot 2 \\
7-2.7 \\
18.7 \\
24.6 \\
11.4 \\
2.4 \\
26.4 \\
15.3 \\
2.2\end{array}$ & $\begin{array}{l}193 \\
474 \\
181 \\
232 \\
341 \\
352 \\
287 \\
340 \\
254 \\
387 \\
529 \\
469 \\
259\end{array}$ & $\begin{array}{l}501 \\
342 \\
706 \\
700 \\
467\end{array}$ & $\begin{array}{l}131 \\
131 \\
68 \\
153 \\
262 \\
267 \\
161 \\
88 \\
319 \\
171 \\
208\end{array}$ & $\begin{array}{l}0.49 \\
0.58 \\
0.26 \\
0.25 \\
0.21 \\
1.13 \\
1.13 \\
0.31 \\
0.31 \\
0.42 \\
\frac{?}{0.44}\end{array}$ & $\begin{array}{l}0.46 \\
1.46 \\
0.15 \\
0.32 \\
0.36 \\
0.81 \\
1.14\end{array}$ & $\begin{array}{c}0.13 \\
0.55 \\
0 \\
0.08 \\
0.11 \\
0.25 \\
0.23 \\
0.16 \\
0.06 \\
0.06 \\
0.7\end{array}$ & \begin{tabular}{|c|}
6 \\
10 \\
$2-4$ \\
10 \\
$4-6$ \\
$8-6$ \\
$8-6$ \\
$4-6$ \\
$4-6$ \\
$4-6$ \\
$4-6$ \\
$4-6$ \\
10 \\
8 \\
4 \\
4
\end{tabular} & $\begin{array}{c}6 \\
10 \\
2-4 \\
10 \\
4-6 \\
8-10 \\
44-6 \\
4-6 \\
4-6 \\
4-6 \\
4-6 \\
10\end{array}$ \\
\hline
\end{tabular}

B. = Mean of two-hour clearance periods immediately before giving drug. 
the days before and immediately after the study for measurement of creatinine clearance. The drug was given by mouth at 2 p.m. when stable urine flows were obtained. The doses were: $20 \mathrm{mg}$ (3); $40 \mathrm{mg}$ (3); $50 \mathrm{mg}$ (3); $60 \mathrm{mg}$ (1); $100 \mathrm{mg}$ (4); $150 \mathrm{mg}$ (2).

Osmolality of fresh urine and plasma samples were determined with an osmometer from Advanced Instruments Inc. Urinary and plasma sodium and potassium were determined on a direct reading flame photometer (Instrumentation Inc.) and chloride on a "Buchler-Cotlove" chloridometer. Creatinine was measured by the method of Hare (1950).

The following calculations were made on the two-hour clearance periods described above:

\section{Urine flow rate}

$$
=\mathrm{V}(\mathrm{ml} / \mathrm{min})
$$

Electrolyte excretion

$$
=\mathrm{U}_{\mathrm{EV}}(\mu \mathrm{Eq} / \mathrm{min})
$$

Per cent. filtered load excreted $=\frac{U_{E V} \times 100}{P_{E} \times G F R \times f}$

where $\mathbf{P}_{\mathbf{E}}$

$$
\begin{aligned}
& =\text { plasma electrolyte concentra- } \\
& \text { tion }(\mathrm{mEq} / \mathrm{l} \text {.) }
\end{aligned}
$$

and $\mathbf{f}$

$$
=\text { Donnan factor* }
$$

Osmotic clearance $\left(\mathrm{C}_{\mathrm{osm}}\right)$

$$
=\frac{\mathrm{V} \mathrm{x} \text { urine osmolality }}{\text { Plasma osmolality }}(\mathrm{ml} / \mathrm{min})
$$

Free water clearance $\left(\mathrm{C}_{\mathrm{H}_{2} \mathrm{O}}\right)=\mathrm{V}-\mathrm{C}_{\mathrm{osm}}(\mathrm{ml} / \mathrm{min})$.

Full haematological indices, liver function tests, and serum transaminases were determined for each patient before and after the study.

\section{Results}

The individual results and their mean values are given in Tables II and III respectively and the latter are shown in Fig. 1. The individual results were used in paired $t$ tests to calculate the

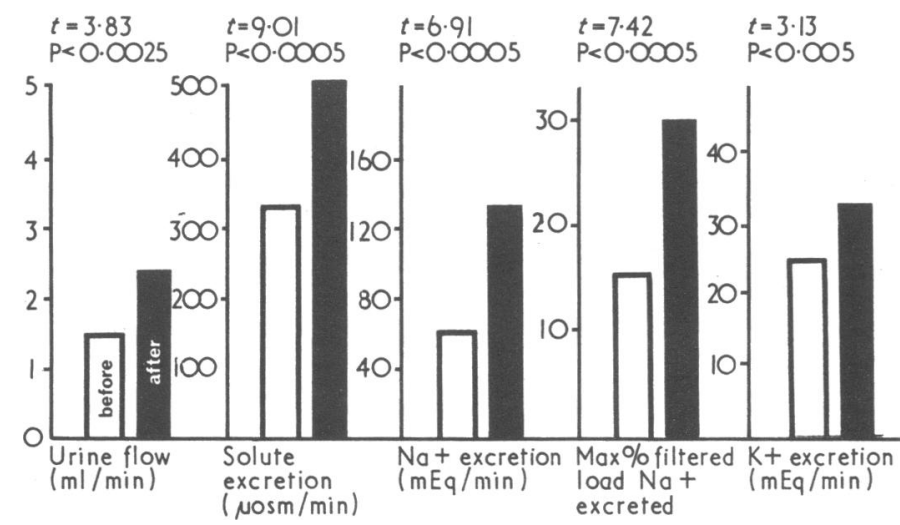

Effect of metolazone on urine flow and solute excretion. Mean values before and after metolazone are shown. Values after drug are peak response period.

significance of each observed increase (Table III). The heights of the diuretic effect occurred on average six hours after the administration of the drug. Although the mean glomerular filtration rate was only $4.2 \mathrm{ml} / \mathrm{min}$, the mean urine flow rate achieved after metolazone was $2.36 \mathrm{ml} / \mathrm{min}$. There was a significant natriuresis, the mean sodium excretion increasing by $113 \%$, and an associated chloruresis. Potassium excretion also increased significantly but to a much lesser degree (33\%). There was no correlation between the glomerular filtration rate and increase in urine flow and electrolyte excretion after metolazone over the narrow range of glomerular filtration rate examined $(1 \cdot 2-12 \mathrm{ml} / \mathrm{min})$. Fractional sodium excretion was closely related

\begin{tabular}{|c|c|c|c|c|c|c|}
\hline & $\begin{array}{l}\text { Urine } \\
\text { Flow } \\
\text { (ml/min) }\end{array}$ & $\begin{array}{c}\text { Solute } \\
\text { Excretion } \\
(\mu 0 \mathrm{sm} / \mathrm{min})\end{array}$ & $\underset{\text { Excretion }}{\mathrm{Na}+}$ & $\underset{\text { Excretion }}{\mathbf{K}+}$ & $\underset{\substack{\text { Maximum } \\
(\%)}}{\text { Maximum }}$ & $\underset{(\mathrm{ml} / \mathrm{min})}{\mathbf{C}_{\mathbf{H}_{\mathbf{2}} \mathrm{O}}}$ \\
\hline $\begin{array}{c}\text { Before } \\
\text { After } \\
\quad \stackrel{t}{\mathbf{P}}\end{array}$ & $\begin{array}{c}1.56 \\
2.36 \\
3.83 \\
<0.0025\end{array}$ & $\begin{array}{c}334 \\
504 \\
9.01 \\
<0.0005\end{array}$ & $\begin{array}{c}58.7 \\
125 \\
6.91 \\
<0.0005\end{array}$ & $\begin{array}{l}25 \\
33 \\
3.13 \\
<0.005\end{array}$ & $\begin{array}{l}15 \\
30 \\
7.42 \\
<0.0005\end{array}$ & $\begin{array}{c}0.39 \\
0.59 \\
2.46 \\
<0.025\end{array}$ \\
\hline
\end{tabular}
to glomerular filtration rate both during control water loading

*The constant governing the distribution of anions and cations on either side of a semi-permeable membrane on one side of which there are protein anions. TABLE III-Mean Values Before and After Metolazone and Results of Paired
$t$ Tests on Individual Results

periods and after the drug. Falling glomerular filtration rate is associated with rising fractional electrolyte excretion, so that maximum fractional sodium excretion was $38 \%$ before and $55 \%$ after metolazone at a glomerular filtration rate of $2 \cdot 2 \mathrm{ml} / \mathrm{min}$. A small but statistically significant increase in free water clearance was found at the height of the diuresis.

\section{Discussion}

These results show that oral metolazone can have a significant natriuretic and diuretic effect even at a very low glomerular filtration rate. Despite the high basal fractional water and electrolyte excretion rates due to the low glomerular filtration rate in these patients, a $51 \%$ increase in mean urine flow rate and a $113 \%$ increase in mean sodium excretion occurred. The time taken to reach the maximum effect, six hours, was greater than the time of two hours shown for non-uraemic subjects by Steinmuller and Puschett (1972). There was a small but statistically significant increase of $33 \%$ in mean potassium excretion. There was no evidence of any major side effects and the oral dose of 20-150 mg was well tolerated.

In dogs and in normal human subjects at a dosage of 4-7.5 mg, metolazone has been shown to have an effect similar to that of hydrochlorothiazide (Materson and Barkin, 1970; Belair et al., 1969; Michelis et al., 1970). Generally, a decrease in free water clearance during water diuresis is seen suggesting an inhibiting effect on sodium reabsorption in the ascending limb of the loop of Henle. In the present patients with advanced renal failure a fall in proximal sodium reabsorption must occur since loss of up to $55 \%$ of the filtered load of sodium is found. The small rise in free water clearance found may be related to this, masking any incomplete blocking action the drug may have on the distal diluting segment.

It is interesting to compare the present results with those of a recent similar study with frusemide (Allison and Kennedy, 1971). Twenty patients with stable, non-oedematous chronic renal disease (mean glomerular filtration rate $6.1 \mathrm{ml} / \mathrm{min}$ ) had control water and electrolyte excretion during water loading not statistically different from those in the present study. Frusemide in a dosage of $100 \mathrm{mg}$ given by mouth or intravenously produced twice as much increase in urine flow rate and sodium excretion (103 and $263 \%$ respectively) and three times as much potassium loss $(91 \%$ increase). In some patients with chronic renal failure high dosage frusemide produced a loss of up to $87 \%$ of filtered sodium and apparently all of the glomerular filtrate. The value of high dosage frusemide in oedematous patients with a very low glomerular filtration rate and in the nephrotic syndrome is now well recognized, as are the side effects that may be associated with such potent therapy (Allison and Kennedy, 1971; Lancet, 1971). Ethacrynic acid may also be effective in such situations (Maher and Schreiner, 1965) but the thiazides and mercurial diuretics are not effective when the glomerular filtration rate is below 15-20 $\mathrm{ml} / \mathrm{min}$ (Reubi and Cottier, 1961).

Oral metolazone has a significant diuretic and natriuretic effect even at a low glomerular filtration rate, and its potency is obviously greater than that of the thiazides and somewhat less than that of frusemide. No side effects have been reported as yet, even after intraventricular injection (Schoonees et al., 1971). It may prove useful, therefore, in the management of chronic renal failure, and we are currently engaged in studies in its longterm use in such patients. 
We would like to express our thanks to Dr. J. Ward Regan, medical consultant to the Pharmaceutical Division of Pennwait Corporation (U.S.A.) for supply of metolazone, and also to the patients who so willingly took part in this trial.

\section{References}

Allison, M. E. M., and Kennedy, A. C. (1971). Clinical Science, 41, 171. Belair, E. J., Kaiser, F., and Van Denburg, B. (1969). Archives Internationales de Pharmacodynamie et de Thérapie, 177, 71.

Dettli, L., and Spring, P. (1966). Annals of the New York Academy of Sciences, $139,471$.

Hare, R. S. (1950). Proceedings of the Society for Experimental Biology and Medicine, 74, 148 .

Lancet, 1971, 2, 803.
Laragh, J. H., Cannon, P. J., Stason, W. B., and Heinemann, H. O. (1966). Annals of the New York Academy of Sciences, 139, 453.

McKenzie, I. F., Fairley, K. F., and Baird, C. W. (1966). Medical fournal of Australia, 1, 879.

Maher, J. F., and Schreiner, G. E. (1965). Annals of Internal Medicine, 62 15.

Materson, B. J., and Barkin, J. S. (1970). Clinical Research, 18, 64.

Michelis, M. F., De Rubertis, F., and Beck, N. P. (1970). Fournal of Clinical Pharmacology and Therapeutics, 11, 821.

Muth, R. G. (1966). Fournal of the American Medical Association, 195, 1066. Muth, R. G. (1968). Annals of Internal Medicine, 69, 249

Reubi, F. C., and Cottier, P. T. (1961). Circulation, 23, 200.

Schoonees, R., Mostert, J. W., Moore, R. H., Stetson, J. B., and Murphy, G. P. (1971). New York State Fournal of Medicine, 71, 566

Silverberg, D. S., and Kjellstrand, C. M. (1968). Acta Medica Scandinarica, 184,473 .

Steinmuller, S., and Puschett, J. B. (1971). American College of Physicians, March, 30.

Steinmuller, S., and Puschett, J. B. (1972). Kidney International, 1, 169.

\title{
Effect of Posture on Glucose Tolerance after Gastric Surgery
}

\author{
C. D. HOLDSWORTH, I. HULME-MOIR, C. THIRUMALAI
}

British Medical fournal, 1972, 4, 198-200

\begin{abstract}
Summary
Oral glucose tolerance after either partial gastrectomy or vagotomy and pyloroplasty for duodenal ulcer was markedly affected by posture. Peak blood glucoses and the degree of reactive hypoglycaemia were greater in the erect than in the supine position. This is probably due to positional changes in gastric emptying, and our findings support the view that after gastric surgery alteration in gastric emptying rate is the main factor responsible for the change in oral glucose tolerance.
\end{abstract}

\section{Introduction}

Glucose tolerance is often abnormal after gastric resection, with a high peak value and a tendency to reactive hypoglycaemia. We have previously presented evidence that this reactive hypoglycaemia is due largely to the altered pattern of gastric emptying rather than to hypersecretion of insulin (Holdsworth et al., 1969). Gastric emptying of a "balanced" fluid meal has been shown to vary greatly with posture after vagotomy and a drainage procedure (McKelvey et al., 1969), and this is also true for $20 \mathrm{~g} / 100 \mathrm{ml}$ of glucose solution after either vagotomy and pyloroplasty or a Polya partial gastrectomy (I. HulmeMoir and C. D. Holdsworth, unpublished observations). We have, therefore, studied the effect of posture on glucose tolerance in patients with gastric and duodenal ulcer before and after surgery.

\section{Patients and Methods}

The subjects studied were a consecutive series of patients referred to a surgical unit with an established diagnosis of benign gastric or duodenal ulcer. Preoperative studies were carried out a few days before surgery. Postoperative studies were carried out several weeks after surgery. Oral glucose tolerance tests were performed after an overnight fast while otherwise

Royal Infirmary, Sheffield

C. D. HOLDSWORTH, M.D., M.R.C.P., Consultant Physician

St. Bartholomew's Hospital, London E.C.1

I. HULME-MOIR, F.R.C.S., Research Fellow in Surgery

C. THIRUMALAI, B.SC., Research Assistant in Medicine on an unrestricted carbohydrate intake using $50 \mathrm{~g}$ of glucose dissolved in $250 \mathrm{ml}$ of orange-flavoured water, and sampling venous blood from an antecubital vein. During supine studies the patient lay on a horizontal table, and during erect studies the patient was seated strictly upright, maintained in this position by a light harness attached to the vertical back of a specially constructed chair.

Blood glucose was measured by a reducing method on a Technicon AutoAnalyzer. Plasma levels of immunoreactive insulin were determined by radioimmunoassay, using dextrancoated charcoal to separate the bound and free fractions (Herbert et al., 1965). The significance of differences in blood glucose and plasma insulin was assessed by Student's $t$ test for unpaired data, as it was not possible to study all patients in the two positions. Statistical analysis of data was carried out only for "peak levels," which are the highest blood glucose or plasma insulin levels recorded during a test, and for the degree of "reactive hypoglycaemia." By reactive hypoglycaemia we mean the maximum fall in blood glucose below fasting levels observed late in the test, between 90 and 150 minutes after ingestion of the glucose meal.

\section{Results}

\section{DUODENAL ULCER}

Preoperative.-Posture had no significant effect on the glucose tolerance (Fig. 1). The peak blood glucose level was only slightly higher during the erect test than during the supine test. Peak plasma insulin levels were also unaffected by posture, mean values being $173 \mu \mathrm{U} / \mathrm{ml}$ during supine tests and $184 \mu \mathrm{U} / \mathrm{ml}$ during the erect tests.

Postoperative.-Two operative procedures were used. Six patients had a procedure, either a Polya gastrectomy or a vagotomy plus antrectomy, which involved gastric resection. Their postoperative glucose tolerance tests are shown in Fig. 2. In contrast to the preoperative findings, posture had a considerable effect on the glucose tolerance, with a peak blood glucose much higher in the erect than in the supine position $(P<0.001)$. Nine patients had a vagotomy and pyloroplasty, and their postoperative glucose tolerance tests are shown in Fig. 3. In these patients the findings were similar and although the effects of the posture were less pronounced the peak glucose in the erect position was again significantly higher $(P<0.001)$ than in the supine position. In the supine position the degree of reactive hypo- 